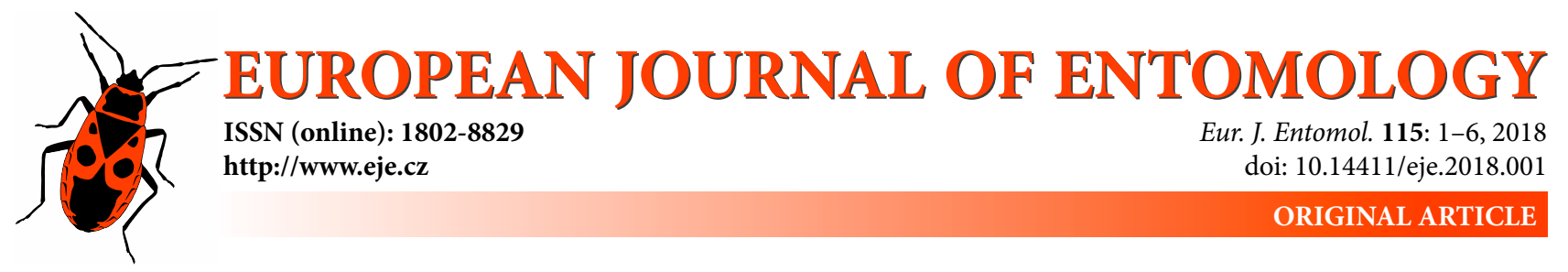

\title{
Puncture vs. reflex bleeding: Haemolymph composition reveals significant differences among ladybird species (Coleoptera: Coccinellidae), but not between sampling methods
}

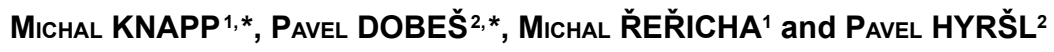 \\ ${ }^{1}$ Department of Ecology, Faculty of Environmental Sciences, Czech University of Life Sciences Prague, Prague, \\ Czech Republic; e-mails: knapp@fzp.czu.cz, rericham@fzp.czu.cz \\ ${ }^{2}$ Department of Animal Physiology and Immunology, Institute of Experimental Biology, Faculty of Science, Masaryk University, \\ Brno, Czech Republic; e-mails: pavel.dobes.sci@gmail.com, hyrsı@sci.muni.cz
}

\begin{abstract}
Key words. Coleoptera, Coccinellidae, Harmonia axyridis, Coccinella septempunctata, Ceratomegilla undecimnotata, invasive species, haemolymph, antimicrobial activity, haemocyte concentration, protein concentration, reflex bleeding, sampling technique
\end{abstract}

\begin{abstract}
Reflex bleeding is one of the many anti-predation behavioural tactics used by insects. This behaviour is recorded widely in several insect taxa and provides scientists with an interesting opportunity for easily obtaining samples of haemolymph for physiological experiments. However, there is no good evidence that haemolymph and reflex blood have the same characteristics. In this study, we compared three basic characteristics of reflex blood and haemolymph collected from the body cavity, of three species of ladybirds: Harmonia axyridis, Coccinella septempunctata and Ceratomegilla undecimnotata. In the reflex blood we recorded the same concentration of haemocytes and total protein, and level of antimicrobial activity against Escherichia coli as in samples of haemolymph collected from within the body cavity. Therefore, reflex blood is a promising source of haemolymph for use in many physiological and immunological studies. It is the best way of collecting haemolymph if one wants to avoid challenging the immune system and concurrently also enables one to repeatedly collect haemolymph from one individual without injuring it, which would initiate repair mechanisms. The interspecific comparison indicates significant differences among the species studied in three characteristics measured. Interestingly, the native species Ceratomegilla undecimnotata has nearly as effective immune system as the invasive Harmonia axyridis based on the level of antibacterial activity against Escherichia coli.
\end{abstract}

\section{INTRODUCTION}

Reflex bleeding is an effective defensive behaviour that is widely distributed among insects, as the reflex blood can contain toxins that are present in the haemolymph. As a reaction to physical attack, haemolymph is released mostly from tibiofemoral articulations (Hodek et al., 2012) and in some cases in Orthoptera even squirted over a distance of several centimetres (Glenn, 1991). Reflex bleeding in insects is an effective defence against various predators, e.g. small mammals, birds, lizards or arthropods (Eisner et al., 2005; Bateman \& Fleming, 2009; Sato et al., 2009; Novgorodova, 2015; Zvereva \& Kozlov, 2016). Reflex bleeding behaviour is described for larvae and/or adults in several insect orders, e.g. Hymenoptera (Boeve \& Schaffner, 2003), Plecoptera (Moore \& Williams, 1990), Orthoptera (Bateman \& Fleming, 2009), Hemiptera (Bugila et al., 2014) and Coleoptera (see below). Among beetles, reflex bleeding is recorded in species belonging to sev- eral families, e.g. Meloidae (Nicolson, 1994), Erotylidae (Drilling \& Dettner, 2010), Lampyridae (Fu et al., 2006), Endomychidae (Shockley et al., 2009) and Coccinellidae (Sato et al., 2009). In some families, e.g. Coccinellidae, this defensive behaviour is recorded in the majority of the species (Hodek et al., 2012).

The externalisation of a chemical defence may be an advantageous strategy, as the predator does not have to injure the prey to be aware of its toxicity (Endler, 1986). A thorough meta-analysis of efficiencies of chemical defence strategies in herbivorous insects indicates that reflex bleeding is among the most effective defensive strategies against predators (Zvereva \& Kozlov, 2016). Reflex bleeding also provides an exceptional opportunity for scientists to obtain easily samples of haemolymph. Insect haemolymph is an important source of material that can be sampled and analysed similar to human blood and is often used in various experimental studies (Jančaříková et al., 2017; Řeřicha et

\footnotetext{
* These authors contributed equally to this work.
} 
al., 2017; Vogel et al., 2017). There is experimental evidence that the externalisation of haemolymph poses a significant physiological cost to insects, because it needs to be replenished. Frequent reflex bleeding during the larval stage could result for instance in a smaller body size of adults (Grill \& Moore, 1998; Sato et al., 2009) or longer larval development (Grill \& Moore, 1998). Zvereva \& Kozlov (2016) also show that species with externalised chemical defence are at a higher risk of parasitization, which could be linked to a weakened immune system. These costs indicate that valuable components of haemolymph are lost during reflex bleeding, as shown by Karystinou et al. (2004) and Kay et al. (1969) for haemocytes. Haematopoiesis is an energy-demanding process and haemocyte loss during reflex bleeding could result in organismal exhaustion. However, to our knowledge, it has not been investigated rigorously whether the reflex blood contains the same concentrations of particular components and the same activity as haemolymph circulating in the body cavity. The most common way of sampling haemolymph is by wounding an insect by a puncture or incision, which inevitably results in the activation of a wound-sealing processes and repair of the damaged cuticle and underlying tissues (Krautz et al., 2014; Lee \& Miura, 2014). In reflex bleeding, the body surface of an insect remains intact, therefore sampling reflex blood provides an alternative method in studies where injuring of experimental insect is undesirable. Furthermore, sampling reflex blood without injuring insects eliminates the risk of infection.

In the current study, we evaluated three characteristics of ladybird haemolymph sampled by means of reflex bleeding and puncturing insects, and compared the results obtained using these two methods of sampling. We focused on the concentration of circulating haemocytes, total protein concentration and antimicrobial activity against Escherichia coli. We measured the above in adults of three species of ladybirds (Ceratomegilla undecimnotata, Coccinella septempunctata and Harmonia axyridis), which means the results are more general than studies based on only a one species. Harmonia axyridis and Coccinella septempunctata are commonly studied ladybirds, which in Europe are, respectively, an invasive and native species. The comparison of these two species was further aimed at testing one of the attributed reasons of the high invasiveness of Harmonia axyridis, which is its supposed efficient immune system (Vogel et al., 2017). To the best of our knowledge, the immune and physiological characteristics of the haemolymph of the last species included in this study, Ceratomegilla undecimnotata, has not been previously investigated. As Ceratomegilla undecimnotata is not invasive species the expectation is that its immune system has a low basal activity compared to Harmonia axyridis.

\section{MATERIAL AND METHODS}

\section{Investigated species}

All the species investigated are large aphidophagous ladybirds (5-8 mm long) belonging to the tribe Coccinellini (Nedvěd, 2015). Harmonia axyridis (Pallas, 1773) is considered to be one of the most invasive species of insect (Brown et al., 2011; Lombaert et al., 2011). This species is native to East Asia, particularly to areas with temperate and subtropical climates (Brown et al., 2008). During the last decades it was introduced many times into many European countries and North America (Lombaert et al., 2010; Brown et al., 2011). This invasive species inhabits various leafy trees and shrubs, less frequently reeds and nettles (Nedvěd, 2015). Harmonia axyridis is thought to have caused the decline of native species of ladybirds of which it is an important intra-guild predator (Raak-van Den Berg et al., 2012; Roy et al., 2012). Coccinella septempunctata Linnaeus, 1758 was the most common large species of aphidophagous ladybird in Europe before the arrival of Harmonia axyridis. Coccinella septempunctata is still very abundant mainly on herbaceous vegetation in meadows and arable fields (Nedvěd, 2015). Coccinella septempunctata is a successful invader of open habitats in North America (Evans, 2004). Ceratomegilla undecimnotata (Schneider, 1792) is a relatively common species inhabiting lowland dry grasslands and arable fields in Europe except in regions north of the Czech Republic. This species, similar to Harmonia axyridis, is well known for aggregating overwintering (Nedvěd, 2015). Overwintering groups on hill tops can consist of thousands of individuals (O. Nedvěd, pers. commun.).

All the specimens analyzed in this study were collected in Prague in late summer 2016. Harmonia axyridis beetles were collected from lime-trees growing in the campus of Czech University of Life Sciences in Prague, Coccinella septempunctata beetles were collected from nettles growing along the banks of the Vltava river in Prague-Sedlec and Ceratomegilla undecimnotata beetles were collected from thistles in Prague-Zličín. The adults of all these species were subsequently reared in the laboratory for at least 14 days to preclude working with young individuals (Řeřicha et al., 2017). The beetles were sexed and placed into Petri dishes in groups of 5 individuals of the same sex and provided with water and food (Ephestia kuehniella eggs) ad libitum. Ladybirds were exposed to a constant temperature of ca. $22^{\circ} \mathrm{C}$ under a natural photoperiod (ca. 14L : 10D).

\section{Sampling procedures and characteristics measured}

Haemolymph of each ladybird was sampled using two techniques. In the first, ladybirds were stimulated by poking their legs with an entomological pin to induce reflex bleeding after which a sample of reflex blood was collected. Immediately after collecting this sample, a sample of the haemolymph from the body cavity was collected by puncturing the metasternum of the ladybird with a sterilized entomological pin (diameter of $0.30 \mathrm{~mm}$ ) and collecting the haemolymph that exuded from the puncture. Prior to collecting the reflex blood or haemolymph the beetles were fixed using double-sided adhesive tape in a specially modified Petri dish lid. Haemolymph was collected using a glass microcapillary (Hirschmann, Germany) and the amount sampled was measured using a digital calliper with a precision of 0.01 $\mathrm{mm}$. A volume of $1 \mu \mathrm{l}$ corresponds to $15 \mathrm{~mm}$ of microcapillary tube length. We aimed to collect a drop of fresh haemolymph (at least $0.5 \mu \mathrm{l}$ ) from a given individual using both methods. When a smaller amount of haemolymph was collected by either method from a given individual, then those samples were not included in the final analyses. The collected haemolymph was diluted $(100 \times$ dilution) in anticoagulant buffer ( $62 \mathrm{mM} \mathrm{NaCl}, 100 \mathrm{mM}$ glucose, $30 \mathrm{mM}$ trisodium citrate, and $26 \mathrm{mM}$ citric acid) and the haemocytes it contained immediately counted. The rest of the diluted haemolymph was stored at $-25^{\circ} \mathrm{C}$ for further analyses. All samples of haemolymph were used to determine the three physiological and immunological characteristics, specifically: concentration 
of circulating haemocytes, protein concentration and antimicrobial activity against Escherichia coli K12.

The number of haemocytes was counted in diluted fresh haemolymph of individual animals using a Bürker chamber viewed under a Carl Zeiss Primo Star microscope (Germany).

Protein concentration in the haemolymph was measured calorimetrically using a Bradford protein assay (Bio-Rad, USA) according to the manufacturer instructions. Absorbance was measured using a plate reader Sunrise (Tecan, Switzerland). Serial dilution of control serum Bio-La-Test ${ }^{\circledR}$ LYONORM (Erba Lachema, Czech Republic) was used as a standard.

The antimicrobial activity of haemolymph against Gram-negative bacteria was measured luminometrically using bioluminescent Escherichia coli K12, which contain a luxABCDEamp plasmid for expression of bacterial luciferase and its substrate, as published (Vojtek et al., 2014; Reřicha et al., 2017). Briefly, $40 \mu \mathrm{l}$ of haemolymph solution with anticoagulant buffer (100× dilution) was mixed in a reaction well with $120 \mu$ of solution containing 100,000 bacterial cells and phosphate buffer (pH 7). The luminescence signal, which is positively correlated with viability of Escherichia coli K12, was recorded using a luminometer Chameleon $\mathrm{V}^{\mathrm{TM}}$ (Hidex, Finland) in counts per second (CPS). The reaction of haemolymph with bacteria was followed for 60 minutes and integrals of luminescence were compared in order to calculate the percentage of bacteria killed by haemolymph. Maximal bacterial luminescence ( $0 \%$ bacteria killed) was measured in each experimental set up as the reaction of $40 \mu \mathrm{l}$ anticoagulant buffer and $120 \mu \mathrm{l}$ of bacterial solution containing 100,000 bacterial cells in a phosphate buffer.

\section{Data analysis}

Data analysis was limited to the dataset that consisted of beetles for which samples were successfully obtained by both sampling methods (reflex bleeding and puncture). For detailed information on the final dataset see Supplementary file S1 Dataset.

To investigate the effect of sampling method, species, sex and interactions between the above mentioned factors on the immune and physiological characteristics of ladybird haemolymph, the generalised linear mixed models (GLMMs) in the "glmmPQL" function implemented in the "nlme" package (Pinheiro et al., 2013) for R (R Development Core Team, 2016) were used. Separate models were used for the different characteristics, namely protein concentration in haemolymph, haemocyte concentration and antimicrobial activity against Escherichia coli. Beetle identity was used as a random effect in all models as pairs of samples (reflex blood and puncture samples) originated from the same animal. Maximal models included sampling method, species, sex and all possible interactions between them as independent variables. These maximal models were subsequently simplified into the final models using a backward selection procedure, which included only significant terms. To identify significant differences between species, Tukey's HSD tests were employed using the "glht" function as implemented in the package "multcomp" (Hothorn et al., 2008). GLMM with a quasi-Poisson distribution of errors was used to analyse haemocyte concentration, GLMM with a gamma distribution of errors and logarithmic link function to analyse total protein concentration and GLMM with a binomial distribution of errors to analyse antimicrobial activity against $E s$ cherichia coli.

\section{RESULTS}

\section{Haemocyte concentration}

Haemocyte concentration did not differ between sampling methods (GLMM: $\mathrm{F}_{1,57}=0.78, \mathrm{P}=0.38$ ), i.e. sam-

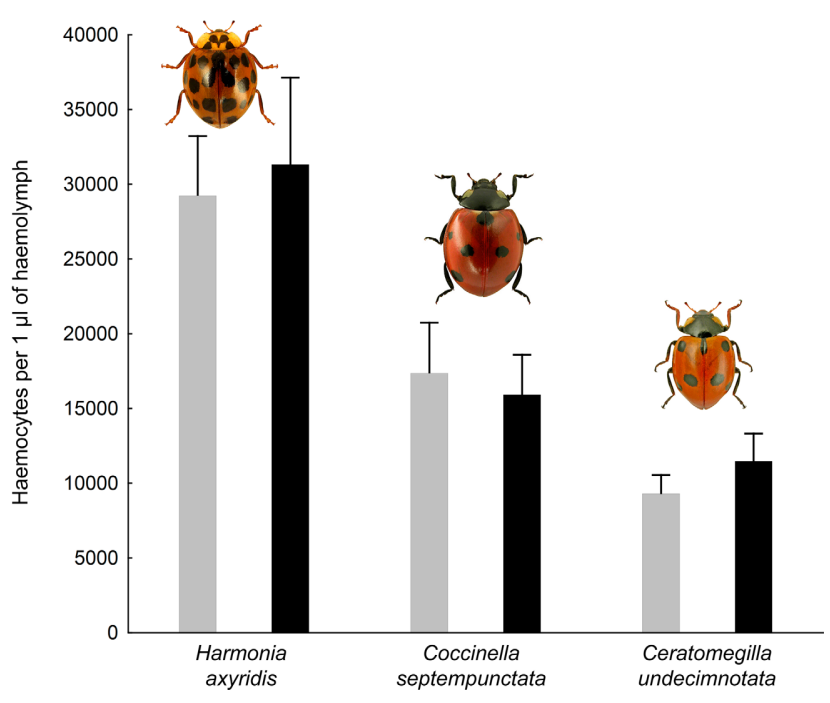

Fig. 1. Concentration of haemocytes in reflex blood and haemolymph obtained using the puncture method recorded for three species of ladybirds. Mean values + SEM are shown separately for each species: Harmonia axyridis ( $n=21$ beetles), Coccinella septempunctata ( $\mathrm{n}=19$ beetles) and Ceratomegilla undecimnotata ( $n=18$ beetles). Grey bars are for reflex blood samples, whereas black bars are for the haemolymph obtained using the puncture method. Data for both sexes were pooled as there are no significant differences in haemocyte concentrations between sexes for any of the species of ladybirds studied.

ples of reflex blood and haemolymph collected from the body cavity using the puncture method contained comparable numbers of haemocytes per microliter. There were no differences in haemocyte concentration between sexes within species (GLMM: $\left.\mathrm{F}_{1,56}=0.14, \mathrm{P}=0.71\right)$, but there were significant differences between species (GLMM: $F_{2,55}$ $=16.28, \mathrm{P}<0.001)$. Harmonia axyridis had a significantly higher haemocyte concentration than both native species, of which Coccinella septempunctata had a slightly higher haemocyte concentration than Ceratomegilla undecimnotata (Fig. 1; Table 1). There were no significant interactions between sampling method, sex and species (GLMM: $\mathrm{P}>0.05$ in all cases).

Table 1. Comparison of three characteristics of haemolymph measured in three species of ladybirds. Reported results are based on Tukey's post-hoc tests applied to generalised linear mixed models comparing concentration of haemocytes, total protein concentration and antimicrobial activity against Escherichia coli K12 of the haemolymph of the following species ladybirds: Ceratomegilla undecimnotata, Coccinella septempunctata and Harmonia axyridis. Significant differences between species (P-values) are highlighted in bold.

\begin{tabular}{lll}
\hline Characteristic & Contrast & z-value P-value
\end{tabular}

Haemocyte concentration Ceratomegilla - Coccinella $-2.373 \quad \mathbf{0 . 0 4 6}$ Harmonia - Coccinella $3.354 \quad \mathbf{0 . 0 0 2}$ Harmonia - Ceratomegilla $5.700<0.001$

Protein concentration Ceratomegilla-Coccinella $1.054 \quad 0.543$ Harmonia - Coccinella $\quad 5.509<\mathbf{0 . 0 0 1}$ Harmonia - Ceratomegilla $4.270<\mathbf{0 . 0 0 1}$

Antimicrobial activity Ceratomegilla - Coccinella $15.024<0.001$ Harmonia - Coccinella $18.600<\mathbf{0 . 0 0 1}$ Harmonia-Ceratomegilla $2.998 \quad \mathbf{0 . 0 0 8}$ 


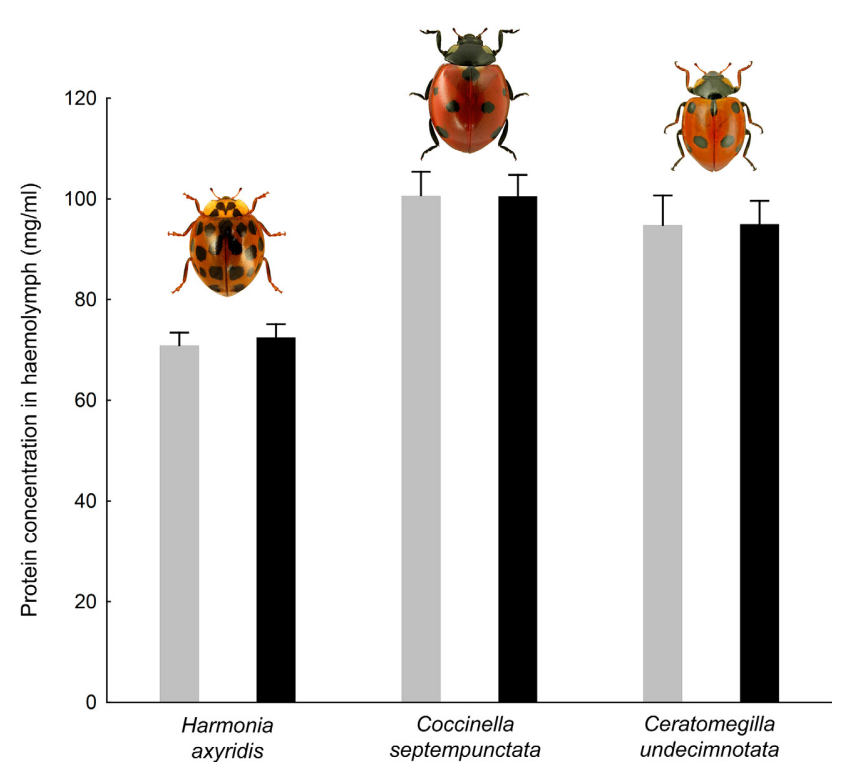

Fig. 2. Concentration of proteins in reflex blood and haemolymph obtained using the puncture method for three species of ladybirds. Mean values + SEM are shown separately for each species: Harmonia axyridis ( $\mathrm{n}=21$ beetles), Coccinella septempunctata ( $\mathrm{n}=19$ beetles) and Ceratomegilla undecimnotata ( $n=17$ beetles). Grey bars are for reflex blood, whereas black bars are for haemolymph obtained using the puncture method. Data for both sexes were pooled as there are no significant differences in protein concentrations between sexes for any species of ladybirds studied.

\section{Protein concentration}

Concentration of protein in haemolymph did not differ between sampling methods (GLMM: $\mathrm{F}_{1,56}=0.21, \mathrm{P}=$ $0.65)$. There were no differences in concentration of protein between sexes within species (GLMM: $\mathrm{F}_{1,55}=0.11, \mathrm{P}=$ $0.74)$, but the differences between species were significant (GLMM: $F_{2,54}=16.48, \mathrm{P}<0.001$ ). The concentration of protein recorded for Harmonia axyridis was significantly lower than that recorded for both native species, between which there was no significant difference (Fig. 2; Table 1). There were no significant interactions between sampling method, sex and species (GLMM: P > 0.05 in all cases).

\section{Antimicrobial activity}

Efficiency of ladybird haemolymph in killing Escherichia coli K12 did not differ between samples collected using the two methods (GLMM: $\mathrm{F}_{1,40}=2.22, \mathrm{P}=0.14$ ). There were no differences in antimicrobial activity of the haemolymph between sexes within species (GLMM: $F_{1,39}$ $=0.91, \mathrm{P}=0.34$ ), but the differences among species were highly significant (GLMM: $\left.\mathrm{F}_{2,38}=173.45, \mathrm{P}<0.001\right)$. Of the three species the antimicrobial activity of the haemolymph of Harmonia axyridis against Escherichia coli bacteria was the highest. That recorded for Ceratomegilla undecimnotata was slightly, but significantly lower than that recorded for Harmonia axyridis, but significantly higher than that recorded for Coccinella septempunctata, which was the least efficient in killing Escherichia coli bacteria (Fig. 3; Table 1). There were no significant interactions between sampling method, sex and species (GLMM: P > 0.05 in all cases).

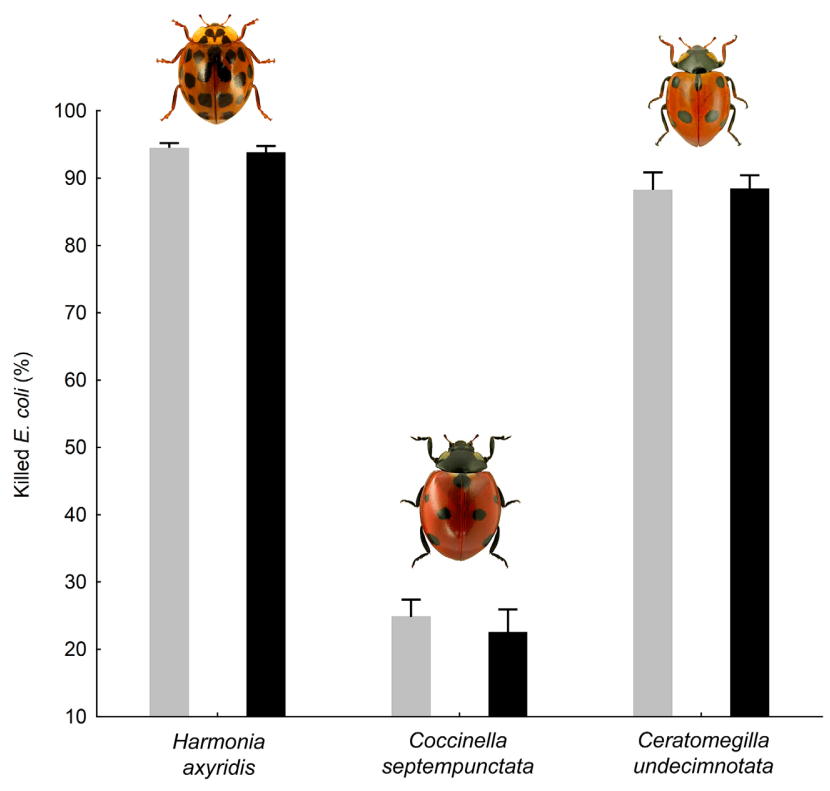

Fig. 3. Antimicrobial activity against Escherichia coli $\mathrm{K} 12$ of reflex blood and haemolymph obtained using the puncture method recorded for three species of ladybirds. Antimicrobial activity is expressed as the percentage of $E$. coli K12 killed (out of 100,000 bacterial cells in $120 \mu \mathrm{l}$ of phosphate buffer) by $0.4 \mu \mathrm{l}$ of undiluted haemolymph in 60 minutes. Mean values + SEM are shown separately for each species: Harmonia axyridis ( $n=16$ beetles), Coccinella septempunctata ( $\mathrm{n}=13$ beetles) and Ceratomegilla undecimnotata ( $\mathrm{n}=12$ beetles). Grey bars are for reflex blood, whereas black bars for haemolymph obtained using the puncture method. Data for both sexes were pooled as there are no significant differences in haemolymph antimicrobial activity between sexes for any of the species of ladybird studied.

\section{DISCUSSION}

We confirmed that ladybird reflex blood contains haemocytes as previously shown by Karystinou et al. (2004) and furthermore the concentration of haemocytes is the same in reflex blood and haemolymph sampled from the body cavity. Moreover, we also show that the concentration of protein in the samples of haemolymph originating from the body cavity (puncture method) and from reflex blood do not differ significantly. This indicates that ladybirds are not able to restrict their losses of proteins in the reflex blood. On the other hand, it is also evident that haemolymph collected by the puncture method is not substantially influenced by protein contaminants originating from damaged tissues. Similar to the haemocyte and protein concentrations, humoral antimicrobial activity against Escherichia coli did not differ between samples of reflex blood and haemolymph obtained using the puncture method.

Altogether our results clearly indicate that reflex blood is an easy way of collecting haemolymph for use in immunological and physiological research. This method is rarely used (Gross et al., 2010) and there is no corresponding methodological study. The use of reflex blood as a source of haemolymph could be beneficial, especially in studies where repeated sampling from adult ladybirds is needed and injury caused by puncturing would have an undesired effect on the response of the insect studied. In such a case, repeated punctures could affect the immune system more 
seriously than repeated reflex bleeding, which seems to be a common event during the life-time of adult ladybirds (Holloway et al., 1991; Hodek et al., 2012). The absence of any mechanism preventing adult ladybirds from losing valuable components of haemolymph, e.g. haemocytes, as a result of reflex bleeding is surprising if we assume that the production of these components entails substantial physiological costs. The evidence on which this assumption is based come from data on ladybird larvae (Sato et al., 2009), but rarely from adult ladybirds. Holloway et al. (1991) and de Jong et al. (1991) show for two species that ladybirds lose up to $10 \%$ or even $12 \%$ of their fresh body mass during reflex bleeding (mean loss was ca $7 \%$ in both species) and recovery of original concentrations of alkaloids (coccinelline and adaline) after reflex bleeding takes several days. Droplets of reflex blood excreted by overwintering ladybirds can cause inoculative freezing of the body and subsequent death at relatively high subzero temperatures (Nedvěd, 1993). Other costs of reflex bleeding in adult ladybirds, e.g. effects on their resistance to pathogens or effects on egg production in females, need to be further studied in future studies. Very low physiological and fitness costs of reflex bleeding are unlikely but are a possible cause of the absence of a filtering mechanism.

Interspecific comparison of the characteristics of reflex blood and haemolymph collected from the body cavity (by puncture) of three different species of ladybirds and the fact that we did not record any difference associated with the two types of collecting haemolymph indicate this might be a general pattern for the tribe Coccinellini. Moreover, we show that the characteristics of haemolymph significantly differ among the species studied. A very efficient immune system is thought to be responsible for the worldwide invasive success of Harmonia axyridis (Vogel et al., 2017). However, comparisons are limited to only a few other species of ladybirds - Coccinella septempunctata and Adalia bipunctata (Gross et al., 2010; Schmidtberg et al., 2013; Vogel et al., 2017). Here we show that another ladybird species native to Europe, namely Ceratomegilla undecimnotata, has a humoral antimicrobial defence against Escherichia coli comparable to that of the invasive species, Harmonia axyridis. In contrast to the antimicrobial activity, the concentrations of haemocytes and protein differed substantially between the invasive species and two native species, but for the exact interpretation of these results a more detailed immunological study is needed. For instance, genome-wide comparison of immune related genes, detailed classification of particular haemocyte types involved in the defence reaction or response of Harmonia axyridis and Ceratomegilla undecimnotata to an immunological challenge could shed new light on the physiological differences between native and invasive species. It is also possible that differences between species are not related to their invasive status, but are a result of the evolutionary history of a species. Based on the recent phylogenetic analyses of true ladybirds (Magro et al., 2010; Escalona et al., 2017), the genera Harmonia and Ceratomegilla are closely related to each other, whereas the genus Coccinella belongs to a different clade.
In conclusion, we suggest that reflex blood is a convenient way of sampling haemolymph for physiological and immunological research. Moreover, the collection of reflex blood is a non-invasive method, which could be important especially in studies where repeated sampling of the same individuals is needed and the activation of repair mechanisms should be avoided. Interestingly, our interspecific comparison of the basic physiological and immunological characteristics showed that some species native to Europe have a constitutive immune activity that is nearly as efficient as that of the invasive species Harmonia axyridis. It will be well worth the effort to complexly compare the functioning of the immune systems of native and invasive species of ladybirds belonging to particular phylogenetic lineages and not just a few model species (e.g. Adalia bipunctata and Coccinella septempunctata).

ACKNOWLEDGEMENTS. We are grateful to J. Knappová for her insightful comments on an early draft of this manuscript. This study was supported by grant no. 42110/1312/3118 awarded by the Internal Grant Agency of the Czech University of Life Sciences Prague.

AUTHOR CONTRIBUTIONS. Conceived and designed the experiments: MK, PD. Performed the experiments: MR̆, MK, PD. Analyzed the data: MK, PD. Contributed reagents/materials/analysis tools: MK, PH. Wrote the paper: MK, PD, Mř.

\section{REFERENCES}

Bateman P.W. \& Fleming P.A. 2009: There will be blood: autohaemorrhage behaviour as part of the defence repertoire of an insect. - J. Zool. 278: 342-348.

Boeve J.L. \& Schaffner U. 2003: Why does the larval integument of some sawfly species disrupt so easily? The harmful hemolymph hypothesis. - Oecologia 134: 104-111.

Brown P.M.J., Adriaens T., Bathon H., Cuppen J., Goldarazena A., Hagg T., Kenis M., Klausnitzer B.E.M., Kovar I., Loomans A.J.M., Majerus M.E.N., Nedvěd O., Pedersen J., Rabitsch W., Roy H.E., Ternois V., ZaKharov I.A. \& Roy D.B. 2008: Harmonia axyridis in Europe: spread and distribution of a non-native coccinellid. - Biocontrol 53: 5-21.

Brown P.M.J., Thomas C.E., Lombaert E., Jefrries D.L., Estoup A. \& HandLEY L.-J.L. 2011: The global spread of Harmonia axyridis (Coleoptera: Coccinellidae): distribution, dispersal and routes of invasion. - Biocontrol 56: 623-641.

Bugila A.A.A., Franco J.C., Da Silva E.B. \& Branco M. 2014 : Defense response of native and alien mealybugs (Hemiptera: Pseudococcidae) against the solitary parasitoid Anagyrus sp nr. pseudococci (Girault) (Hymenoptera: Encyrtidae). - J. Insect Behav. 27: 439-453.

De Jong P.W., Holloway G.J., Brakefield P.M. \& De Vos H. 1991: Chemical defence in ladybird beetles (Coccinellidae). II. Amount of reflex fluid, the alkaloid adaline and individual variation in defence in 2-spot ladybirds (Adalia bipunctata). Chemoecology 2: 15-19.

Drillig K. \& Dettner K. 2010: First insights into the chemical defensive system of the erotylid beetle, Tritoma bipustulata. Chemoecology 20: 243-253.

EISNer T., Eisner M. \& Siegler M.V.S. 2005: Secret Weapons: Defenses of Insects, Spiders, Scorpions, and Other Many-legged Creatures. Harvard University Press, Cambridge, 372 pp.

ENDLER J.A. 1986: Defense against predators. In Feder M.E. \& Lauder G.V. (eds): Predator-prey Relationships: Perspectives 
and Approaches from the Study of Lower Invertebrates. University of Chicago Press, Chicago, pp. 109-134.

Escalona H.E., Zwick A., Li H., Li J., Wang X., Pang H., HartLey D., Jermin L.S., NedvĚd O., Misof B., Niehuis N., ŚliPinSKI A. \& TomaszewsKa W. 2017: Molecular phylogeny reveals food plasticity in the evolution of true ladybird beetles (Coleoptera: Coccinellidae: Coccinellini). - BMC Evol. Biol. 17: $151,11 \mathrm{pp}$.

Evans E.W. 2004: Habitat displacement of North American ladybirds by an introduced species. - Ecology 85: 637-647.

Fu X.H., Nobuyoshi O., Meyer-Rochow V.B., Wang Y.Y. \& Le C.L. 2006: Reflex-bleeding in the firefly Pyrocoelia pectoralis (Coleoptera: Lampyridae): Morphological basis and possible function. - Coleopt. Bull. 60: 207-215.

GLENN G.S. 1991: A systematic revision of Enyaliopsis Karsh 1887 (Orthoptera, Tettigoniidae, Hetrodiane). - Trans. Am. Entomol. Soc. 117: 67-102.

GriLl C.P. \& Moore A.J. 1998: Effects of a larval antipredator response and larval diet on adult phenotype in an aposematic ladybird beetle. - Oecologia 114: 274-282.

Gross J., Eben A., Mueller I. \& Wensing A. 2010: A well protected intruder: The effective antimicrobial defense of the invasive ladybird Harmonia axyridis. - J. Chem. Ecol. 36: $1180-1188$

HodeK I., van EMden H.F. \& HonĚK A. 2012: Ecology and Behaviour of the Ladybird Beetles (Coccinellidae). Willey-Blackwell, Chichester, $561 \mathrm{pp}$.

Holloway G.J., De Jong P.W., Brakefield P.M. \& De Vos H. 1991: Chemical defence in ladybird beetles (Coccinellidae). 1 . Distribution of coccinelline and individual variation in defence in 7-spot ladybirds (Coccinella septempunctata). - Chemoecology 2: 7-14.

Hothorn T., Bretz F. \& Westfall P. 2008: Simultaneous inference in general parametric models. - Biometrical J. 50: 346363.

JančaŘí́xová G., Houser J., Dobeš P., Demo G., Hyršl P., WiMMEROVÁ M. 2017: Characterization of novel bangle lectin from Photorhabdus asymbiotica with dual sugar-binding specificity and its effect on host immunity. - PLoS Pathog. 13: e1006564, $28 \mathrm{pp}$

Karystinou A., Thomas A.P.M. \& Roy H.E. 2004: Presence of haemocyte-like cells in coccinellid reflex blood. - Physiol. Entomol. 29: 94-96.

Kay D., Rothschild M. \& Aplin R. 1969: Particles present in the haemolymph and defensive secretions of insects. - J. Cell Sci. 4: $369-379$.

Krautz R., Arefin B. \& Theopold U. 2014: Damage signals in the insect immune response. - Front. Plant Sci. 5: 342, 11 pp.

LeE W.J. \& Miura M. 2014: Mechanisms of systemic wound response in Drosophila. - Curr. Top. Dev. Biol. 108: 153-183.

Lombaert E., Guillemaud T., Cornuet J.M., Malausa T., Facon B. \& Estoup A. 2010: Bridgehead effect in the worldwide invasion of the biocontrol harlequin ladybird. - PLOS ONE 5: e9743, 7 pp.

Lombaert E., Guillemaud T., Thomas C.E., Handley L.J.L., Li J., Wang S., Pang H., Goryacheva I., Zakharov I.A., Jousselin E., Poland R.L., Migeon A., van Lenteren J., De Clerce P., Berkvens N., Jones W. \& Estoup A. 2011: Inferring the origin of populations introduced from a genetically structured native range by approximate Bayesian computation: case study of the invasive ladybird Harmonia axyridis. - Mol. Ecol. 20: 4654-4670.

Magro A., Lecompte E., Magne F., Hemptinne J.L. \& CrouauRoY B. 2010: Phylogeny of ladybirds (Coleoptera: Coccinellidae): are the subfamilies monophyletic? - Mol. Phylogenet. Evol. 54: 833-848.
Moore K.A. \& Williams D.D. 1990: Novel strategies in the complex defense repertoire of a stonefly (Pteronarcys dorsata) nymph. - Oikos 57: 49-56.

NEDVĚD O. 1993: Comparison of cold hardiness in two ladybird beetles (Coleoptera: Coccinellidae) with contrasting hibernation behaviour. - Eur. J. Entomol. 90: 465-470.

NEDVĚD O. 2015: Ladybird Beetles (Coccinellidae) of Central Europe. Academia, Prague, 304 pp.

Nicolson S.W. 1994: Water replenishment following reflex bleeding in the blister beetle Decapotoma lunata Pallas (Coleoptera: Meloidae). - Afr. Entomol. 2: 21-23.

Novgorodova T.A. 2015: Role of social and individual experience in interaction of the meadow ant Formica pratensis (Hymenoptera: Formicidae) with ladybird imagines and hoverfly larvae. - Insect Sci. 22: 440-450.

Pinheiro J., Bates D., Debroy S., Sarkar D. \& R Development Core Team 2013: Nlme: linear and nonlinear mixed effects models. R Package Ver. 3.1-107. https://cran.r-project.org/web/ packages/nlme/nlme.pdf

R Development Core Team 2016: R: A Language and Environment for Statistical Computing. R Foundation for Statistical Computing, Vienna, URL http://www.R-project.org.

RaAk-van den Berg C.L., De Lange H.J. \& van Lenteren J.C. 2012: Intraguild predation behaviour of ladybirds in semi-field experiments explains invasion success of Harmonia axyridis. - Plos ONE 7: e40681, 11 pp.

ŘEŘıICHA M., Dobeš P., HyRšL P. \& KNAPP M. 2017: Ontogeny of protein concentration, hemocyte concentration and antimicrobial activity against Escherichia coli in hemolymph of the invasive harlequin ladybird, Harmonia axyridis (Coleoptera: Coccinellidae). - Physiol. Entomol. DOI: 10.1111/phen.12224.

Roy H.E., Adriaens T., IsaAc N.J.B., Kenis M., OnKelinx T., SAN Martin G., Brown P.M.J., Hautier L., Poland R., Roy D.B., Comont R., Eschen R., Frost R., Zindel R., van Vlaenderen J., Nedvěd O., Ravn H.P., Gregoire J.C., De Biseau J.C. \& MAES D. 2012: Invasive alien predator causes rapid declines of native European ladybirds. - Divers. Distrib. 18: 717-725.

Sato S., KuShiBUChI K. \& YASUdA H. 2009: Effect of reflex bleeding of a predatory ladybird beetle, Harmonia axyridis (Pallas) (Coleoptera: Coccinellidae), as a means of avoiding intraguild predation and its cost. - Appl. Entomol. Zool. 44: 203-206.

Schmidtberg H., Roehrich C., Vogel H. \& Vilcinskas A. 2013: A switch from constitutive chemical defence to inducible innate immune responses in the invasive ladybird Harmonia axyridis. — Biol. Lett. 9: 20130006, 4 pp.

Shockley F.W., Tomaszewska K.W. \& Mchugh J.V. 2009: Review of the natural history of the handsome fungus beetles (Coleoptera: Cucujoidea: Endomychidae). - Insecta Mundi 72: 1-24.

Vogel H., Schmidtberg H. \& Vilcinskas A. 2017: Comparative transcriptomics in three ladybird species supports a role for immunity in invasion biology. - Dev. Comp. Immunol. 67: 452-456.

Vojtek L., Dobes P., Buyukguzel E., Atosuo J. \& Hyrsl P. 2014: Bioluminescent assay for evaluating antimicrobial activity in insect haemolymph. - Eur. J. Entomol. 111: 335-340.

Zvereva E.L. \& Kozlov M.V. 2016: The costs and effectiveness of chemical defenses in herbivorous insects: a meta-analysis. - Ecol. Monogr. 86: 107-124.

Received October 6, 2017; revised and accepted November 27, 2017 Published online January 9, 2018

Supplementary file:

Table S1 (http://www.eje.cz/2018/001/S01.xlsx). The raw data in Microsoft Excel's .xlsx format. 